\title{
Two ARL Approaches to Counting Holdings of Research Libraries
}

By A. F. KUHLMAN

\begin{abstract}
A T THE TWENTY-FIRST MEETING of the Association of Research Libraries (ARL) held in New York City, March 2, 1944, Robert B. Downs brought up the need for more uniform standards of statistics of library holdings. He believed a committee should be appointed to attempt to standardize such statistics.

In the discussion that followed, Donald Coney expressed the view that titles were more important than volumes in determining holdings. Errett W. McDiarmid proposed that processed volumes be counted, since many volumes are neither cataloged nor accessioned. Downs replied that the number of volumes organized and ready for use should be the criterion. Henry B. Van Hoesen questioned the need for uniform statistics or the real value of comparing them. A motion was then passed to appoint a committee to attempt to develop standard practices in statistics. ${ }^{1}$
\end{abstract}

A Committee on Statistics of Library Holdings was appointed in January 1945, with Downs as chairman. It made its first report at the twenty-third meeting of ARL on June 22, 1945 in New York City, recommending that library holdings and annual additions be reported in terms of bibliographical items. After some discussion, Downs moved the adoption of the report. His motion was seconded and it passed.

While the report was adopted, the ARL Minutes do not indicate for what purpose it was adopted but it was suggested that the report be sent to member

1 ARL Minutes 21:16.

This article is based primarily upon the action of the Association of Research Libraries as reported in the Minutes of its meetings. A positive microfilm of the Minutes for meetings 1 through $42,1932-54$, is available from the Microreproduction Laboratory of the Massachusetts Insitute of Technology for $\$ 10$.
Dr. Kuhlman is Director, Joint University Libraries, Nashville, Tennessee.

institutions of ARL for their study and advice. It was realized that there were real difficulties in changing statistics, both because it would upset comparative statistics of past years and because it would be expensive to recount. The executive secretary, Paul North Rice, was directed to send at least ten copies of the report to every member institution of ARL. ${ }^{2}$

The result of this action was that many libraries sent in criticisms and suggestions and the Downs committee revised its report and presented it at the twentyfourth meeting in Chicago, December 2930,1945 . Downs admitted that virtually all libraries commenting on the recommendations indicated that they would not make the system retroactive but could put it into effect for current acquisitions. He also stated that "considerably more than a majority of the Association's members answered the Committee's questions, some of them sending detailed comments and criticisms dealing with the preliminary recommendations. With this additional background, the Committee believes the subject has been adequately explored, and that the proposals it is now prepared to offer are practicable, reasonable and will be generally adopted, if approved by the Association." 3

The report was then accepted with the understanding that the chairman of the committee consult with the Library Service Division and with the ALA Commit: tee on Statistics and that he then have

\footnotetext{
2 ARL Minutes, 23:7, 19-20.
}

3 ARL Minutes $24: 8,16-18$. 
the report published in a library periodical. This was done in an article in the Library Quarterly, January 1946.

In his article Downs went beyond the report of his ARL committee. He developed a helpful statement on difficulties involved in counting library holdings. He acknowledged that the most widely used system of counting holdings was by physical volumes and that to change established routines and apply new rules retroactively would be an undertaking of great magnitude, particularly for large libraries. He discussed the merits and limitations of three methods of measuring library holdings: the physical volume count, the bibliographical unit count, and measuring linear feet of materials on shelves.

In discussing the unit for counting he used the definitions of a volume adopted by ALA and the United States Office of Education and a more specific definition by Randolph G. Adams, stressing that a volume is any bibliographical item with a title or title page which is fully prepared for use. Accessibility was stressed as a criterion in the definitions, and by Downs, as the prime factor in counting volumes. Counting should be confined to materials intended to form part of the permanent research collection.

Downs favored counting by bibliographical items. He recommended that in counting multiple items bound between two covers one should record as a volume any item which has a title or title page of its own and which would be counted as a volume if bound separately. But he was aware of the danger of "padding." To avoid it, a number of items bound between two covers probably should not be regarded as separate bibliographical units if they constitute a connected series. Thus, "to count every document in the collected edition of a government's publications as a bibliographical unit would swell total figures for library holdings to almost astronomical proportions."
Downs also included a discussion of -some of the factors responsible for lack of uniformity in statistics of holdings of different libraries. A separate count of important non-volume material by type was recommended, such as: manuscripts, microproductions, sound-recordings, music scores, maps, and prints.

The committe's recommendations for counting were summarized at the end of Downs' article.

At the twenty-fifth meeting of ARL, June 19, 1946 in Buffalo, New York, Downs reported that he had met the directive of the Association of contacting the Library Service Division and ALA Committee on Statistics, that he assumed his report was now officially adopted by the ARL and he expressed the hope that members of the Association would put the committee's recommendations into practice, insofar as feasible. ${ }^{4}$

At the twenty-sixth meeting of ARL, December 29, 1946 in Chicago, its executive secretary, Paul North Rice, reported he had received inquiries about how many ARL members had put into operation the method of keeping statistics recommended by the ARL committee. The chairman then asked the group how many had adopted the new plan. Representatives of three libraries-Illinois, Indiana, and the Library of Congress-indicated their libraries had done so. Thereupon, Downs was requested to make a survey of ARL members to determine how many had adopted the scheme. 5

At the twenty-seventh meeting of ARL in Washington in March 1947, Downs presented by title only his report of the ARL Committee on Statistics of library holdings and it was reproduced as an appendix to the minutes of the meeting.

The inquiry made by the committee was answered by thirty libraries-twothirds of the ARL membership. About one-half of those replying appeared to

\footnotetext{
4 ARL Minutes 25:6.
}

5 ARL Minutes 26.6. 
be following all, or a substantial part of the committee's recommendations. This group included most of the largest research libraries in the country. Most of the other libraries replying stated that their statistics were based upon accession records, i.e., the physical volume count. Two difficulties were reported to a general adoption of a count of holdings by bibliographical items: (1) Libraries would have to make a retroactive count of their entire collection to be consistent, and they could not afford it; and (2) the committee's recommendations would currently add to the cost of compiling statistics because they called for more complete records.

A majority of those replying, said Downs, regarded uniformity in statistics of library holdings as desirable, but many doubted its feasibility. Downs concluded: "Obviously, statistics will mean little unless agreements can be reached on some common rules. As time goes on, libraries following different practices will go farther apart rather than closer, and will no longer be comparable." 6

At the thirtieth meeting of ARL in Chicago, January 30, 1948, the executive secretary, Charles W. David, urged the reopening of the question of how to count library holdings since it had not been settled to the satisfaction of all concerned. Downs stated he was not adverse to having the matter reopened and he moved that the ARL Committee on Statistics be reconstituted with a new membership. The motion was seconded and carried unanimously. ${ }^{7}$

At the thirty-first meeting of ARL, June 11, 1948 in Philadelphia the new committee, under the chairmanship of Guy R. Lyle, was authorized to devise and recommend some simple method of recounting book stocks and to report back to a later meeting of the Association. 8

Lyle's committee on Counting Library

A ARL Minutes $27: 13,26$.

7 ARL Minutes 30:9.
8 ARL Minutes $31: 18$.
Holdings presented its report, dated January 13, 1949, at the thirty-second meeting of ARL on January 20, 1949 in Chicago. He asked that his committee be discharged, but it was pointed out that so important a report deserved far more careful consideration than could be given to it at that meeting. He was urged, and he agreed, to permit the committee to remain in being at least until the next meeting when it was hoped the report could be given careful consideration and important decisions could be made. ${ }^{9}$

The committee had recommended the "physical count," in preference to the "bibliographical unit," and had worked out rules for the former method. On March 3, 1949, the executive secretary, Charles W. David, distributed the report of the Committee on Counting Library Holdings to the membership and transmitted Lyle's request that at the Cambridge meeting of ARL on March 31, 1949 members should express a preference for one of the two methods. Members unable to attend that meeting were to send their vote by mail to the executive secretary in advance of the meeting.

The report of the Lyle Committee on Counting Library Holdings described briefly why it had decided to recommend the physical volume count. In May of 1948 , the committee inquired of seventyfive libraries, including all ARL members, as to which of three methods of counting holdings they preferred. Replies from fifty-nine libraries were received-twenty-three favored a count by bibliographical unit, thirty-two a count by physical volume and four a count by piece. Only twenty-eight ARL members replied. Of these, eleven favored a count by bibliographical unit and seventeen a count by physical volume.

In its preliminary deliberations the Lyle Committee was struck by two things: (1) No one, apparently, had ever bothered to establish clearly the rules

- ARL Minutes 32:32, 55-59. 
for counting by physical volume such as the Downs committee had done for counting by bibliographical unit. (2) The committee doubted seriously whether any change would make for greater uniformity in counting for libraries beyond a certain size. "In view of the variety and complexity of materials received by a large research library, the committee felt that no concept of uniformity in counting could be more than ideal."

Since the relative merits of the two systems could not be determined until the rules for counting by physical volumes were formulated, the committee drew up a plan for counting by physical volume.

After studying both methods of counting the committee concluded that counting by physical volume is preferable to counting by bibliographical unit because: (1) Most libraries are now committed to a count by physical volume. A change to a retroactive count of bibliographical units would be burdensome and expensive. (2) The count by physical volume can incorporate many of the good features of the bibliographical unit method of counting without exaggerating or inflating statistics. The committee in a sub-appendix showed the difference in count of eight titles selected at random. These, counted bibliographically, totaled 141 units but counted by physical volumes they represented only 19 volumes. (3) The physical volume count is easier than counting by bibliographical unit. (4) Counting by physical volume is simple and inexpensive to administer.

At the thirty-third meeting of ARL, at Cambridge on March 31, 1949,10 the executive secretary, Charles W. David, opened the discussion of the report of Lyle's Committee on Statistics by recalling that in March 1947 the ARL had voted its approval of a method of counting library holdings by bilbiographical units rather than by physical volumes. Many libraries, however, had not ac-

\footnotetext{
10 ARL Minutes 33:11-14.
}

cepted this decision, and there had been numerous protests. Thereupon a new committee had been appointed under the chairmanship of Mr. Lyle and its report had been distributed to ARL members at the preceding meeting in January. Lyle had urged that a formal vote of the Association be taken as to method of counting library holdings.

In the discussion that followed, Downs, chairman of the earlier committee which had recommended counting by bibliographical unit, said "that he had once thought uniformity possible but that he had become disillusioned on this subject and believed that no action taken here would have much effect." He thought one more expression of preference would be futile and therefore moved that the report of the committee be accepted and that the committee be discharged with thanks. His motion was voted down16 to 9 .

Thereupon letters were presented that had been received by Lyle. G. Flint Purdy, who had been chairman of the committee of ACRL which had annually compiled statistics for college and university libraries, said that he thought the Lyle committee had done an extraordinarily good job and that the method of counting by physical volumes (rather than by bibliographical unit) as recommended by Lyle's committee seemed to him "to be about as far as we can go at the moment in establishing a standard and practicable means of measuring the contents of libraries." He and Ralph M. Dunbar (letter to Lyle) of the Library Service Division suggested methods for refining the committee's recommendations of counting by physical volumes.

A vote taken on the two methods of counting showed that ARL members stood as follows: Twelve favored counting by bibliographical unit and twentynine favored counting by physical volume.

It was suggested that ARL members, in reporting for the annual Princeton

COLLEGE ANDRESEARCH LIBRARIES 
statistical compilation, hereafter indicate which method of counting they have used. This recommendation was unanimously approved, but unfortunately has not been observed by all libraries following the bibliographical count. The report of the Lyle Committee was published in the January 1950 issue of $C R L$, pp. 69-72.

Thus the Association of Research Libraries has wrestled with the problem of counting holdings of research libraries in the work of two able committees: the Downs committee, favoring counting of volume material in terms of bibliographical items, plus separate counts for various types of non-volume material; and Lyle's committee, favoring the physical volume count. Each committee has supplied definitions and rules for the method of counting it favored. With both plans before it, the Association voted 29 to 12 favoring the physical volume count. Eleven years have passed since this vote was taken and they seem to have proved that Downs was right when he said at Cambridge in March 1949 that he believed any action taken by ARL would have little effect in producing uniformity in counting holdings.

Now, in 1960 , we seem to be reaching a situation that Downs warned against at the ARL meeting in Washington in March 1947 when he said, "statistics will mean little unless agreements can be reached on some common rules [for counting holdings]. As time goes on, libraries following different practices will go farther apart rather than closer, and will no longer be comparable." We may well have reached that state already.

If the university libraries that have reported their holdings in terms of bibliographical items had only earmarked them as such, that would have helped somewhat. But it still would not have told by what percentage the number of physical volumes in a given library had been inflated, whether by 20 per cent, 30 per cent, 40 per cent, or what.
Whether we like it or not the size of university libraries has become a factor in institutional rivalry in attracting topflight faculty members and graduate students. That is one good reason why statistics should be made as comparable as possible.

Two sources seem primarily responsible for an inflationary count when the bibliographical unit is used:

1. In the rules for counting by bibliographical unit the Downs committee recommended at the December ARL meeting in Chicago in 1945 that: "In counting multiple items bound between two covers, record as a volume any item having a title or title page of its own, and which would be counted as a volume if bound separately, i.e., base statistics on bibliographical units." 11 To follow this rule in counting monographic material and a great mass of official governmental publications would result in serious padding. Thus for instance, at the Joint University Libraries the Hearings of the 85th Congress have been assembled, bound and counted in 185 physical volumes. But to apply the bibliographical measuring rod would swell the count to at least 1,085 .

2. Equally serious inflation of counting holdings arises from counting microprints and microcards each as a volume, for in many cases it requires many microcards to reproduce a single physical volume.

It is no wonder that at the recent ARL meeting in Chicago on January 27, 1960 the urgent need for uniform policies in counting library holdings was stressed by Jens Nyholm. No action was taken by the ARL group because it was thought action should be deferred until the ALA Statistics Coordinating Committee makes its report. It is to be hoped that that Committee will produce standards that will provide greater uniformity in counting library holdings.

11 ARL Minutes 24:16-17. 